\title{
Establishing student perceptions of an entrepreneur using word associations
}

\author{
Authors: \\ Jasmine E. Goliath \\ Shelley M. Farrington ${ }^{1}$ \\ Shelley B. Saunders ${ }^{1}$ \\ Affiliations: \\ ${ }^{1}$ Department of Business \\ Management, Nelson \\ Mandela Metropolitan \\ University, South Africa

\section{Correspondence to: \\ Jasmine Goliath \\ Email: \\ jasmine.goliath2@nmmu. ac.za} \\ Postal address: \\ PO Box 77 000, Port Elizabeth \\ 6031, South Africa

\section{Dates:} \\ Received: 31 Oct. 2013 \\ Accepted: 16 Jan. 2014 \\ Published: 09 May 2014 \\ How to cite this article: \\ Goliath, J.E., Farrington, \\ S.M. \& Saunders, S.B., \\ 2014, 'Establishing \\ student perceptions of an \\ entrepreneur using word \\ associations', Acta Commercii \\ 14(2), Art. \#239, 9 pages. \\ http://dx.doi.org/10.4102/ \\ ac.v14i2.239

\section{Copyright:} \\ (C) 2014. The Authors. \\ Licensee: AOSIS \\ OpenJournals. This work \\ is licensed under the \\ Creative Commons \\ Attribution License.
}

Orientation: To understand entrepreneurial behaviour, it is important to understand the image or perceptions associated with entrepreneurship.

Research purpose: To identify the image or perceptions that students have of an entrepreneur.

Motivation for study: By establishing the image or perceptions that students have of an entrepreneur, insights could be provided into the factors influencing them to become entrepreneurs or not.

Research approach, design and method: A qualitative projective technique, namely continuous word association, was adopted. Convenience sampling was used and 163 students participated. The words generated were coded into categories by searching for themes and words of a similar nature. The total words generated, the frequencies of recurring words, the number of different types of words, first words recalled and the average number of words recalled were established.

Main findings: The students participating in the study have a good understanding of the general nature of an entrepreneur and entrepreneurship; an entrepreneur is perceived as someone who is a creative and innovative risk-taker, who owns a business involved in the selling of goods and services.

Practical/managerial implications: Future entrepreneurs need to be aware that, in addition to several innate attributes, successful entrepreneurs have learned skills and competencies. It is also important that educators of entrepreneurship create a realistic image of what it is like to be an entrepreneur, and that both positive and negative aspects are highlighted.

Contribution/value-add: By identifying the image or perceptions of an entrepreneur held by students, the marketing of entrepreneurship as a desirable career choice can be enhanced.

\section{Introduction and background to this study}

Entrepreneurship as a source of economic growth and competitiveness, as well as job creation and the advancement of social interests, is well documented (Dabic et al. 2012:317; Davey, Plewa \& Struwig 2011:335; Nagy et al. 2010:19; Morris, Pitt \& Berthon 1996:59). Despite these important contributions to the economies of countries, a shortage of entrepreneurial activity exists across borders (Xavier et al. 2012:7) and specifically in developing countries such as South Africa (Simrie et al. 2011:4). The Global Entrepreneurship Monitor studies undertaken over the last 10 years confirm that South Africa has a lower-than-expected entrepreneurial activity rate (Simrie et al. 2011:19). In addition, few South Africans show an intention to start their own business despite a large percentage perceiving entrepreneurship as a good career choice (Xavier et al. 2012:56).

Although various studies (Friedman \& Aziz 2012; Simrie et al. 2011; Xavier et al. 2012) have been undertaken to determine the reasons for the low levels of entrepreneurial activity in South Africa, seeking answers to what drives entrepreneurship remains one of the most important issues in management research (Drost 2010:28). Several authors (Brown, Beale \& White-Johnson 2011; Cañizares \& García 2010; Davey et al. 2011; Gelderen et al. 2008; Kautonen, Van Gelderen \& Tornikoski 2013; Paço et al. 2011) have made use of intentions-based models in attempting to explain why some people become entrepreneurs and others do not. The theory of planned behaviour (TPB) (Ajzen 1991), one of the most commonly used models (Dabic et al. 2012; Davey et al. 2011; Guerrero et al. 2010; Paço et al. 2011), proposes that the greater the intention to engage in a particular behaviour, the more likely will be the performance of that behaviour (Kautonen et al. 2013:698). According to the TPB, intentions are predicted by three things: attitude towards a behaviour, subjective norms regarding the behaviour and the perceived behavioural control over the behaviour (Dabic et al. 2012:319).

Several studies (Gray, Farrington \& Sharp 2010; Lüthje \& Franke 2003; Pihie 2009) have shown that attitude towards a behaviour has the strongest influence on entrepreneurial intentions. 'Attitude 
towards a behaviour' refers to how positive a person feels about the behaviour, and depends on expectations and beliefs about the personal impact of outcomes resulting from the behaviour. The more positive the attitude of an individual towards the behaviour, the more likely it is that the behaviour in question will be performed (Bergmann 2002; Kakkonen 2010). According to Urban, Botha and Urban (2010:115), one's attitude is determined by one's beliefs or perceptions about a particular behaviour, and Zaitadol (2009:340) defines attitude defines attitude towards entrepreneurship as a person's perception of being an entrepreneur (Kolvereid 1996; Kolvereid \& Isaksen 2006).

Image as a measure of perception has been used in numerous fields of study, specifically in the field of marketing with reference to brand image (Guerrero et al. 2010; Prayag 2010; Roininen, Arvola \& Lahteenmaaki 2006; Sester et al. 2013; Simms \& Trott 2006). According to Vahie and Paswan (2006:70), an image is the sum of associations that are positioned in an individual's mind with regard to a certain concept and it is these associations that lead to an individual's overall perceptions of that given concept. These associations are formulated through cognitive reasoning and are based on what the individual knows about the functional attributes of the concept, as well as how the individual feels based on the psychological attributes of the concept (Pritchard \& Frank 2010:1018).

Free association and word association tests are popular techniques used when measuring image (Prayag 2010; Simms \& Trott 2006). Word association techniques provide a true reflection of the internal thoughts and feelings of the research subject, owing to the use of a vague, ambiguous and unstructured stimulus (Donoghue 2000:47; Guerrero et al. 2010:226). Tausczik and Pennebaker (2009:30) contend that words reveal information pertaining to people's priorities, their intentions, where their attention is and what they are trying to avoid. This suggests that words could be used to determine the image or perceptions that individuals have of an entrepreneur, as deeper meanings and underlying associations can be revealed. It can thus be argued that techniques similar to those used in marketing to determine the image or perception of a subject can be used in the field of entrepreneurship to determine the position that an entrepreneur occupies in the mind of potential and current entrepreneurs. To better understand entrepreneurial behaviour it is important to understand the image associated with entrepreneurship (Sester et al. 2013:476).

Studies show that the image of entrepreneurship amongst students in the European Union (Jakubczak \& Rakowska 2013:1003) is not positive; as such, more negative than positive associations are related to being an entrepreneur. The extent to which the image or perceptions associated with an entrepreneur result in positive or negative associations amongst South African students is unknown. Since image measures the perception of a given concept, and perception in turn influences the attitude towards behaviour, it can be argued that if the image of an entrepreneur can be determined, then one can establish whether that image, held in the minds of stakeholders, positively or negatively influences their intentions. By identifying the image or perceptions that individuals have of an entrepreneur, their underlying feelings and attitudes towards such persons, and the career these persons have chosen, could possibly be unveiled. In doing this, possible explanations can be sought for the lack of entrepreneurial intention and activity in South Africa. Once the image associated with an entrepreneur has been established, efforts can be made to overcome negative associations, and positive associations can be used to encourage individuals in relevant target groups to consider becoming an entrepreneur. By identifying the image or perceptions of an entrepreneur held by students, the marketing of entrepreneurship as a desirable career choice can be enhanced.

\section{Purpose and primary objective}

The purpose of this study is to determine the image or perception of an entrepreneur in the eyes of potential entrepreneurs (students). In order to establish this image or perception the concept of 'entrepreneur' was subjected to a word association test amongst students. Through word associations, a more realistic and detailed image or perception of an entrepreneur can be revealed (Prayag 2010:463).

Against the background given above, the primary objective of this study was to identify the image or perception that potential entrepreneurs (students) have of an entrepreneur. These perceptions were established by means of a qualitative projective technique, namely continuous word association tests. According to Stephan et al. (1987:182), if entrepreneurs are positively perceived by people, the likelihood of those individuals becoming entrepreneurs increases. By establishing the image or perceptions that individuals have of an entrepreneur it is hoped that insights will be provided into the factors influencing individuals to become entrepreneurs.

\section{An entrepreneur as described in the literature}

In the general literature on entrepreneurship, the most commonly discussed topics are the nature of entrepreneurship, the attributes (personality traits, characteristics and skills) associated with an entrepreneur, the various push and pull factors and the various rewards and drawbacks of the career. It is these aspects of entrepreneurship that students will most likely have been exposed to, and these aspects that will have influenced their image or perceptions of an entrepreneur

\section{Nature of entrepreneurship}

The term 'entrepreneurship' means different things to different people. According to Bennett (2006:167), an 'entrepreneur' broadly refers to an individual who initiates and manages new business ventures by bringing together the factors of production. Murphy, Liao and Welsch (2006:13) add that entrepreneurship involves the discovery, evaluation and utilisation of future goods and services. Despite there being no consensus on how to specifically define the nature 
of entrepreneurship, certain distinctions differentiate an entrepreneur from a business manager or small business owner (Bennett 2006:167). Small business owners or managers tend to be driven by the resources they control, and the extent to which they control these resources dictates their behaviour and intentions (Morris et al. 1996:61). Small businesses show a preference for low risk and low return, as the venture exists only to support the lifestyle of the small business owner (Kao, Kao \& Kao 2002:18). Alternatively, an entrepreneur is driven by opportunity and change, is dynamic and strategy orientated, whilst seeking growth and business value appreciation (Morris et al. 1996:61).

\section{Entrepreneurial attributes}

In order to create a psychological profile of potential entrepreneurs, various studies (Davey et al. 2011; Elmuti, Khoury \& Abdul-Rahim 2011; Nagy et al. 2010) have attempted to identify attributes and skills prevalent amongst successful entrepreneurs. According to Alstete (2008:585), when describing the nature of an entrepreneur, motivational aspects, personality characteristics and general thematic attitudes, habits and behaviours need to be considered. Bennett (2006:168) suggests that the aspirations of entrepreneurs often differ from those of non-entrepreneurs, and certain attributes or characteristics are more prevalent amongst entrepreneurs than in others, including small business owners or managers. Bennett (2006:168) and Alstete (2008:585) describe these distinguishing attributes as being able to take initiative, being willing to take risks, having selfconfidence, perseverance, resourcefulness, independence, persuasiveness and a tolerance for uncertainty and ambiguity, as well as being a visionary and a charismatic leader. Cañizares and García (2010:786) add that other prevalent entrepreneurial attributes are originality and innovation, moderate risk aversion, acceptance of individual responsibility, long-term planning, the need for achievement, self-confidence, optimism, creativity and autonomy. Alstete (2008:586) contends that when combinations of these attributes are present in an individual, the nature of entrepreneurship may appeal to that individual, which in turn motivates them to become an entrepreneur.

\section{Push and pull factors}

When discerning between factors that motivate entrepreneurship as a career choice, reference is made to 'push and pull' factors. Dawson (2012:698) broadly defines these factors as positive and negative motivations to becoming an entrepreneur. According to Kirkwood (2009:346), push factors are personal or external factors with negative associations that leave individuals with entrepreneurship as one of few career choices. Alternatively, pull factors are attributes and characteristics of entrepreneurship that appeal to an individual, or positive associations that influences them to adopt entrepreneurship as a career choice (Kirkwood 2009:346). Orhan and Scott (2001:235) identify push factors such as dissatisfaction with previous employment owing to a lack of stimulation or prospective career development.
Necessity caused by retrenchment or dismissal and having difficulty in finding other employment is also considered a push factor. Kirkwood (2009:348) notes that the desire for independence and a strong need for achievement that cannot be fulfilled in a current salaried position are powerful pull factors. Orhan and Scott (2001:235) identify a desire to transform an opportunity or social need into a marketable idea as an important pull factor. Dawson (2012:699) and Kirkwood (2009:348) consider monetary or financial reasons to be one of the biggest drivers of entrepreneurial intention, seeing that it can be considered both a necessity and a desire.

\section{Rewards and drawbacks of entrepreneurship}

Different people seek different types of fulfilment from entrepreneurship or a specific combination of rewards that will satisfy their intrinsic needs. Most entrepreneurs regard entrepreneurship as offering several rewards (Alstete 2008:585). These rewards or benefits commonly include the ability to make one's own money, ensuring financial security, being independent, leaving a difficult employment situation and flexibility of personal and family time (Alstete 2008:585). In addition to these advantages, Bosch, Tait and Venter (2011:108) add that the opportunity to make a difference is often considered a benefit of entrepreneurship, especially in South Africa which is characterised by unemployment and poverty. Reaching one's full potential through entrepreneurship is another benefit which would otherwise be difficult in a work environment that is unexciting, unchallenging and frustrating (Bosch et al. 2011:108).

Despite the rewards or benefits of entrepreneurship, numerous disadvantages and unattractive features exist. Alstete (2008:590) identifies several common drawbacks of entrepreneurship, the most prevalent being stress and the long hours that have to be endured considering that the entrepreneur is solely accountable and responsible for all aspects of the business. Stress and commitment of time are adverse characteristics that such a career often has on an entrepreneur's family. Entrepreneurs often risk their personal and business assets and resources to supplement their business ventures, and no guarantee exists that the business will be successful. Thus Bosch et al. (2011:109) note that one of the biggest drawbacks of entrepreneurship is the exposure to business and financial risks. Other drawbacks noted by Alstete (2008:590) include dealing with rapid industry change, hiring appropriately qualified and competent employees, the lack of healthcare and retirement benefits that were previously afforded as an employee and the occasional isolation and loneliness faced by entrepreneurs.

\section{Research methodology}

A qualitative research paradigm was adopted for this study. The concept of 'entrepreneur' is well established and defined in the literature, but how the concept is interpreted or understood in practice is not. A qualitative research approach offers a suitable tool to assess the mental representations of an entrepreneur as held by individuals, thereby revealing how they perceive the concept (Roininen et al. 2006:20) 
Various methods exist by which to analyse qualitative data. Given the purpose and objective of this study, a projective technique was considered most appropriate. Projective techniques involve a form of indirect questioning which results in a better reflection of how the subject (concept) is perceived by a subject (participant). Projective techniques are used to overcome a subject's unwillingness to reveal their true feelings and perceptions, and to unlock hidden or suppressed meanings (Cooper \& Schindler 2006:205). More specifically, the projective technique called a word association test was used. In word association tests participants are given a stimulus word or picture and are then asked to write down a certain number of words that come to mind. The aim of word association tests is the retrieving of associations from the participant's associative or semantic memory (Koll, Von Wallpach \& Kreuzer 2010:588). The continuous word association technique is adopted in this study. This technique involves presenting a stimulus word once to participants, who are required to give as many responses as they can in a specified time. Continuous word association test make it possible to compare the first and the last words of associations, repetition of words and pathways of associations (Kostova \& Radoynovska 2008:211). A continuous word association test allows for unrestricted responses and ensures that because of the time constraint imposed, the research subjects keep on track and continue to give responses to the original stimulus word (Nielsen \& Ingwersen 1999:18).

\section{Sampling and data collection}

Non-business students from the Nelson Mandela Metropolitan University (NMMU) enrolled for a module in entrepreneurship were requested to participate in the word association test. The test was administered during the first lecture of an entrepreneurship module. According to Stephan et al. (1987:182), investigating the image that students have of an entrepreneur is a viable research avenue because students have a high potential to become successful entrepreneurs. As such, convenience sampling was adopted. This sampling method was adopted because of the accessibility and availability of the sample. In addition, owing to time constraints, convenience sampling was used because it is quick, convenient and inexpensive (Hair et al. 2003:217; Struwig \& Stead 2001:111).

In the continuous word association test, participants were asked to write down the words or phrases that came to mind when thinking of the term 'entrepreneur', which was the stimulus word. Participants were asked to recall as many words as possible within a 10- minute period. They were also asked to provide demographic details pertaining to their age, gender, ethnicity, qualification for which they were enrolled and whether they were related to an entrepreneur.

\section{Reliability and validity (rigour or trustworthiness)}

According to Cremer et al. (2010:190), consideration needs to be taken when classifying the responses received from participants because of the researcher's subjective interpretation of the responses. To ensure the reliability of the data collected, Donoghue (2000:50) suggests coder or interpreter reliability as one of the best methods to ensure reliability in projective techniques. This assurance of reliability entails two or more equally competent researchers interpreting the data. If the interpretations differ significantly, then the categorising needs to be questioned. In the present study, three researchers, who are competent in the field of entrepreneurship, analysed and interpreted the words retrieved from the participants. Where interpretations differed significantly, the word categorisation was questioned through logical argumentation to establish consensus.

Donoghue (2000:50) defines 'validity' as the degree to which a particular research instrument measures what it is intended to measure. In terms of projective techniques, specifically when using word association techniques, 'validity' refers to interpreting the data the way the participant understood or meant it. Nielsen and Ingwersen (1999:19) refer to the process of categorising and disregarding irrelevant words as 'interactive activation'. As mentioned with reliability, Donoghue (2000:50) recommends that to ensure the validity of the data, the interpreters need to be skilled, so as to categorise and interpret the responses. As mentioned above, three competent researchers were involved in the analysis and interpretation of the data, and the categorisation process was guided by the entrepreneurship literature.

\section{Coding framework and analyses}

Gibson and Brown (2009:178) describe 'coding' as the process of applying categories to sections of data and collating the similarities and relationships between those categories. The search for themes and codes was facilitated and guided by an in-depth investigation of the entrepreneurship literature. In studies on brand image, the components of image are considered to be tri-structured in nature, consisting of cognitive (what the individual knows), affective (how the individual feels) and holistic (overall symbolism, combination of affective and cognitive) evaluations (Baglou \& Mccleary 1999:870; Prayag 2010:473). However, holistic evaluations were subcategorised under a general category due to the low frequency of holistic terms relative to the other categories. The words generated by the participants in this study were broadly coded according to these categories. The words generated were then further subcategorised by searching for themes within the broad categories to provide more salient and accurate interpretations. In each subcategory synonyms and similar words were grouped together. The categorisation process occurred over a period of time, during which the various words generated were grouped according to recurring themes. Three researchers were involved in the categorisation process and consensus was reached through logical argumentation. When analysing the data, the total words generated, the frequencies of recurring words, the number of different types of words, first words recalled and the average number of words recalled were established. 


\section{Results}

\section{Profile of participants}

The participants in this study were students studying social sciences at NMMU. In total 163 students participated in the word association test. Most (44.10\%) of the students were studying towards either a BA Psychology degree or a Bachelor of Human Movement Science degree (22.09\%). The majority of participants were female $(66.87 \%)$, with most being White students (42.33\%). Black (38.04\%), Mixed race $(12.88 \%)$ and Asian (1.84\%) students made up the rest of the sample. Of the 163 students who participated, 55.83\% indicated that they were related to an entrepreneur.

\section{Word associations with 'entrepreneur'}

From the word association test, a total of 1417 words were generated by the 163 participants in this study, an average of 8.69 words per participant. As per the coding framework the words generated were categorised into three broad categories: cognitive, affective or general in nature (see Table 1$)$. The majority $(61.61 \%)$ of words generated were of a cognitive nature, being based on the participants' knowledge of the term 'entrepreneur'. Only $24.91 \%$ of the words were categorised as general association and $13.61 \%$ as affective associations. General associations are terms that are neither cognitive nor affective in nature and include holistic, operational and unrelated words. Affective associations represent emotional and psychological feelings and motives towards the stimulus word 'entrepreneur'.

Cognitive associations (61.61\%) were further categorised into three subcategories, synonyms, attributes and skills and competencies. Synonyms refer to words that could replace or are similar in meaning to the stimulus word. Words categorised as attributes related to personality or character traits of an entrepreneur, whilst skills and competencies represented learned abilities associated with an entrepreneur. Words relating to the attributes $(81.67 \%)$ possessed by an entrepreneur were the most recalled cognitive evaluations, followed by synonyms (12.94\%) and skills and competencies (5.38\%). Affective associations (13.61\%) were subcategorised as positive or negative; $86.39 \%$ of the words generated in this category were positive and $13.61 \%$ were negative.
General associations (24.91\%) were subcategorised as holistic, operational or unrelated words. Holistic words were those that represented an overall, global or symbolic impression of the stimulus word. Of the general associations, 58.36\% of the words generated were in the holistic subcategory. The subcategory operational included words describing the functional activities or processes involved in running a business. In the general category, $39.94 \%$ of the words generated were subcategorised as operational. A category for unrelated terms was also created for words where a direct relationship could not be established in the context of the present study. Only $1.70 \%$ of the words generated fell into this subcategory.

From Table 1 it can be seen that the number of different words (D) in each category and subcategory varied. The participants in this study associated entrepreneurs with 56 different attributes. Only nine different skills and competencies were identified and more positive (19) than negative words (13) were associated with an entrepreneur. Only four different words could not be directly related to entrepreneurship.

The various words generated in the broad and subcategories described in Table 1 are elaborated on in the paragraphs below. From Table 2, it can be seen that in the cognitive category, the most frequently recalled synonyms were business founder (33.63\%), business-owning person (33.63\%), innovator (11.50\%), self-employed (9.73\%), facilitator (4.42\%) and trader (2.65\%). In the attributes subcategory the most frequently recalled words were risk-taker (11.08\%), creative (8.84\%), innovative and original $(7.99 \%)$, profit orientated $(6.17 \%)$, goal and achievement orientated $(5.89 \%)$, opportunistic $(5.33 \%)$, leader $(4.91 \%)$ and hardworking $(4.35 \%)$. In the skills and competencies subcategory the most frequently occurring words were management skills (21.28\%), knowledgeable (19.15\%), communication and negotiation skills $(17.02 \%)$, sales and retail skills $(10.64 \%)$, time management skills $(10.64 \%)$, financial $(8.15 \%)$ and business $(6.38 \%)$ knowledge, educated $(4.26 \%)$ and life skills (2.13\%).

In the affective category, the following positive associations were most frequently mentioned: makes money $(26.67 \%)$, own boss $(16.36 \%)$, freedom and independence $(12.12 \%)$, job creator $(11.52 \%)$, self-sustaining $(7.88 \%)$, wealth $(6.06 \%)$ and success (4.24\%). The most frequently occurring negative associations were stressful (19.23\%), working long hours (15.38\%), owing money

TABLE 1: Word association categories and sub-categories $(n=1417)$.

\begin{tabular}{|c|c|c|c|c|c|c|c|c|c|}
\hline \multirow[t]{2}{*}{ Categories } & \multicolumn{9}{|c|}{ Sub-categories } \\
\hline & Synonyms & Attributes & $\begin{array}{c}\text { Skills and } \\
\text { competencies }\end{array}$ & Positive & Negative & Holistic & Operational & Unrelated & Total \\
\hline \multirow[t]{3}{*}{ Cognitive } & 12.94 & 81.67 & 5.38 & - & - & - & - & - & $61.61(\%)$ \\
\hline & 113 & 713 & 47 & - & - & - & & - & $873(N)$ \\
\hline & 7 & 56 & 9 & - & - & - & - & - & $72(D)$ \\
\hline \multirow[t]{3}{*}{ Affective } & - & - & - & 86.39 & 13.61 & - & - & - & $13.48(\%)$ \\
\hline & - & - & - & 165 & 26 & - & - & - & $191(N)$ \\
\hline & - & - & - & 19 & 13 & - & - & - & $32(D)$ \\
\hline \multirow[t]{3}{*}{ General } & - & - & - & - & - & 58.36 & 39.94 & 1.70 & $24.91(\%)$ \\
\hline & - & - & - & - & - & 206 & 141 & 6 & $353(N)$ \\
\hline & - & - & - & - & - & 13 & 16 & 4 & $33(D)$ \\
\hline
\end{tabular}

$\%$, category percentage of total words generated; $N$, Total number of words in category/subcategory; $D$, Number of different words. 
TABLE 2: Classification of the words associated with the stimulus word 'entrepreneur'.

\begin{tabular}{|c|c|c|}
\hline Categories & Sub-categories & Description \\
\hline \multirow[t]{3}{*}{$\begin{array}{l}\text { Cognitive } \\
61.61 \%\end{array}$} & $\begin{array}{l}\text { Synonyms } \\
12.94 \%\end{array}$ & $\begin{array}{l}\text { Business founder (33.63\%); business-owning person (31.86\%); innovator }(11.50 \%) \text {; self-employed }(9.73 \%) \text {; facilitator }(4.42 \%) \text {; } \\
\text { trader }(2.65 \%) \text {. }\end{array}$ \\
\hline & $\begin{array}{l}\text { Attributes } \\
81.67 \%\end{array}$ & $\begin{array}{l}\text { Risk-taker }(11.08 \%) \text {; creative }(8.84 \%) \text {; innovative and original }(7.99 \%) \text {; profit orientated }(6.17 \%) \text {; goal and achievement } \\
\text { orientated }(5.89 \%) \text {; opportunistic }(5.33 \%) \text {; leader }(4.91 \%) \text {; hard working }(4.35 \%) \text {; organiser }(3.65 \%) \text {; motivated }(3.51 \%) \text {; } \\
\text { visionary }(2.66 \%) \text {; committed and dedicated }(2.38 \%) \text {; self-confident }(2.38 \%) \text {; ambitious }(2.38 \%) \text {; networker }(2.10 \%) \text {; intelligent } \\
\text { and smart thinkers }(1.96 \%) \text {; business orientated }(1.82 \%) \text {; responsible and accountable }(1.68 \%) \text {; flexible }(1.54 \%) \text {; determined } \\
\text { (1.54\%); initiative }(1.26 \%) \text {; inspiring }(1.26 \%) \text {; passionate }(0.98 \%) \text {; courageous }(0.84 \%) \text {; optimistic }(0.84 \%) \text {; persistent }(0.84 \%) \text {; } \\
\text { tother }(10.10 \%) \text {. }\end{array}$ \\
\hline & $\begin{array}{l}\text { Skills and competencies } \\
5.38 \%\end{array}$ & $\begin{array}{l}\text { Management skills }(21.28 \%) \text {; knowledgeable }(19.15 \%) \text {; communication and negotiation (17.02\%); sales and retail }(10.64 \%) \text {; } \\
\text { time management }(10.64 \%) ; \text { financial knowledge }(8.51 \%) \text {; business knowledge }(6.38 \%) \text {; educated }(4.26 \%) \text {; life skills }(2.13 \%) \text {. }\end{array}$ \\
\hline \multirow[t]{2}{*}{$\begin{array}{l}\text { Affective } \\
13.48 \%\end{array}$} & $\begin{array}{l}\text { Positive } \\
86.39 \%\end{array}$ & $\begin{array}{l}\text { Makes money }(26.67 \%) \text {; own boss }(16.36 \%) \text {; freedom and independence }(12.12 \%) \text {; job creator }(11.52 \%) \text {; self-sustaining } \\
(7.88 \%) \text {; wealth }(6.06 \%) \text {; success }(4.24 \%) \text {; tother }(15.15 \%) \text {. }\end{array}$ \\
\hline & $\begin{array}{l}\text { Negative } \\
13.61 \%\end{array}$ & $\begin{array}{l}\text { Stressful }(19.23 \%) \text {; work long hours }(15.38 \%) \text {; owe money }(11.54 \%) \text {; crime }(7.69 \%) \text {; loss }(7.69 \%) \text {; makes ends meet }(7.69 \%) \text {; } \\
\text { cunning }(7.69 \%) \text {; exploitation }(3.85 \%) \text {; unhealthy }(3.85 \%) \text {; drop out }(3.85 \%) \text {; sacrifice }(3.85 \%) \text {; ambiguous }(3.85 \%) \text {. }\end{array}$ \\
\hline \multirow[t]{3}{*}{$\begin{array}{l}\text { General } \\
24.91 \%\end{array}$} & $\begin{array}{l}\text { Holistic } \\
58.36 \%\end{array}$ & $\begin{array}{l}\text { Business (33.96\%); macro environment }(17.48 \%) \text {; financing }(15.53 \%) \text {; managerial position }(9.71 \%) \text {; market environment } \\
(6.80 \%) \text {; labour }(4.37 \%) \text {; work }(3.40 \%) \text {; physical facilities }(2.91 \%) \text {; individual }(2.91 \%) \text {; role models }(1.46 \%) \text {; luck }(0.49 \%) \text {; } \\
\text { change }(0.49 \%) \text {; business studies }(0.49 \%) \text {. }\end{array}$ \\
\hline & $\begin{array}{l}\text { Operational } \\
39.94 \%\end{array}$ & $\begin{array}{l}\text { Selling of goods and services (41.13\%); marketing }(15.60 \%) \text {; planning and strategy }(10.64 \%) \text {; accounting }(7.80 \%) \text {; production } \\
(7.80 \%) \text {; meeting and schedule }(3.55 \%) \text {; tother }(13.48 \%) \text {. }\end{array}$ \\
\hline & $\begin{array}{l}\text { Unrelated } \\
1.70 \%\end{array}$ & Stakeholders $(50.00 \%)$; small $(16.67 \%)$; expectations (16.67\%); thought $(16.67 \%)$. \\
\hline
\end{tabular}

$\dagger$, Words occurring fewer than five times have been grouped as 'other'.

A complete list of words generated can be requested from the authors.

(11.54\%), crime $(7.69 \%)$, exploitation $(3.85 \%)$, unhealthy $(3.85 \%)$, drop out (3.85\%), sacrifice (3.85\%) and ambiguous (3.85\%).

The most frequently occurring words in the holistic subcategory, which forms part of the general category, were business $(33.96 \%)$, macro environment $(17.48 \%)$, financing $(15.53 \%)$, managerial position $(9.71 \%)$, market environment $(6.80 \%)$ and labour $(4.37 \%)$. The most frequently occurring operational words were goods and services $(41.13 \%)$, marketing (15.60\%), planning and strategy (10.64\%), accounting (7.80\%), production $(7.80 \%)$ and meetings and schedules $(3.55 \%)$. Words and the frequencies with which they occurred that had no direct relationship (unrelated) to the stimulus word 'entrepreneur' included stakeholders (50.00\%), small (16.67\%), expectations (16.67\%) and thought (16.67\%).

From Table 3 it can be seen that the word business was the word generated first, the most times (holistic; 29 times); this was followed by the words business owning person (synonyms; 18 times) and risk-taker (attributes; 15 times). This implies that for $38 \%$ of the participants these were the first words that came to mind when confronted with the word 'entrepreneur'. Regarding the words generated second, business (holistic; 13 times), makes money (positive; 13 times) and creative (attributes; 12 times) were mentioned most frequently. The words generated in the third position that occurred most frequently were risk-taker (attributes; 13 times) profit orientated (attributes; 9 times) and innovative and original (attributes; 9 times).

The most frequently recurring words are summarised in Table 4. The first, third and fifth words occurring most frequently relate to the attributes possessed by an entrepreneur. These words were risk-taker (79 times), creative (63 times) and innovative and original (57 times). The second and fourth most frequently occurring words were business (70 times) and selling of goods and services (58 times). The sixth and seventh most occurring words were profit orientated (44 times) and makes money (44 times).
TABLE 3: Positioning of words.

\begin{tabular}{|c|c|c|c|}
\hline Word position & Word & Sub-category & $N$ \\
\hline \multirow[t]{3}{*}{ First } & Business & Holistic & 29 \\
\hline & $\begin{array}{l}\text { Business-owning } \\
\text { person }\end{array}$ & Synonyms & 18 \\
\hline & Risk-taker & Attributes & 15 \\
\hline \multirow[t]{3}{*}{ Second } & Business & Holistic & 13 \\
\hline & Makes money & Positive & 13 \\
\hline & Creative & Attributes & 12 \\
\hline \multirow[t]{3}{*}{ Third } & Risk-taker & Attributes & 13 \\
\hline & Profit orientated & Attributes & 9 \\
\hline & $\begin{array}{l}\text { Innovative and } \\
\text { original }\end{array}$ & Attributes & 9 \\
\hline
\end{tabular}

TABLE 4: Most frequently recurring words ( $n=1417)$.

\begin{tabular}{llll}
\hline Word & Category & Subcategory & $N$ \\
\hline Risk-taker & Cognitive & Attributes & 79 \\
Business & General & Holistic & 70 \\
Creative & Cognitive & Attributes & 63 \\
Selling of goods and services & General & Operational & 58 \\
Innovative and original & Cognitive & Attributes & 57 \\
\hline Profit orientated & Cognitive & Attributes & 44 \\
Makes money & Affective & Positive & 44 \\
Goal and achievement & Cognitive & Attributes & 42 \\
orientated & Cognitive & Synonyms & 38 \\
Business founder & Cognitive & Attributes & 38 \\
Opportunistic & Cognitive & Synonyms & 36 \\
Business-owning person & General & Holistic & 36 \\
Macro environment & Cognitive & Attributes & 35 \\
Leader & General & Holistic & 32 \\
Financing & Cognitive & Attributes & 31 \\
Hard working & Affective & Positive & 27 \\
Own boss & Cognitive & Attributes & 26 \\
Organiser & Cognitive & Attributes & 25 \\
Motivated & General & Operational & 22 \\
Marketing & Affective & Positive & 20 \\
Freedom and independence & General & Holistic & 20 \\
Managerial position & Cognitive & Attributes & 19 \\
Visionary & Affective & Positive & 19 \\
\hline Job creator & & & \\
\hline & & & \\
\hline
\end{tabular}




\section{Discussion of findings}

The primary objective of this study was to identify the image or perceptions that potential entrepreneurs (students) had of the concept of 'entrepreneur'. These perceptions were established by means of continuous word association tests.

The findings show that the words (1417) generated by the 163 participants were of either a cognitive $(61.61 \%)$, general $(24.91 \%)$ or affective $(13.48 \%)$ nature. The cognitive category referred to words concerning what the individual knows, whereas the affective category words referred to how the individual feels. Given that the participants in this study were students, having no actual experience of being entrepreneurs, it comes as no surprise that the majority of words generated were those relating to what they know about an entrepreneur versus how they feel about one. The great majority of words generated related to the management or entrepreneurship literature. This implies that the participants in this study had had prior exposure to entrepreneurship and had some understanding of what the field entailed.

The great majority of the words generated in the cognitive category related to the attributes possessed by an entrepreneur, whereas only a small percentage related to the learned skills and competencies possessed by these people. This implies that the participants in this study saw an entrepreneur as a person with innate attributes more than a person with learned abilities. Based on this finding it is possible to suggest that students who perceive themselves as lacking these attributes perceive that they lack the ability to become an entrepreneur. Furthermore, the participants in this study did not associate learned skills and competencies with being an entrepreneur.

Although only a few words generated fell under the affective category, it is interesting to note that the great majority of these words were positive in nature. This finding implies that the participants in this study were more positive than negative towards entrepreneurship. Interestingly, only $27 \%$ of participants cited an entrepreneur as a person who makes money. Under the general association category the majority of words related to an overall, global or symbolic impression (holistic) of entrepreneurship or to the functional activities and processes (operational) involved in entrepreneurship. Very few of the words generated in this category were completely unrelated to entrepreneurship. This implies that the students participating in this study did have a broad general understanding of what entrepreneurship entails. This is supported by the fact that the words business and business owning person were cited first most frequently, and that $43 \%$ and $22 \%$ of the students cited these words.

The findings of this study show that the words occurring most frequently related to the attributes possessed by an entrepreneur. Fifty-six different attributes were cited, the most often being risk-taker, creative and innovative and original. Nearly half of the participants $(48.5 \%)$ considered an entrepreneur to be a risk-taker. Furthermore, $71 \%$ considered an entrepreneur to be someone who is creative and innovative and original. It should be noted that many of the attributes cited (e.g. trusting, patient and serious) are not specifically associated with an entrepreneur, as in the entrepreneurship literature.

One can conclude that the students participating in this study had a good understanding of the general nature of an entrepreneur and entrepreneurship. An entrepreneur was perceived by them to be a person who is a creative and innovative risk-taker, and who owns a business involved in the selling of goods and services.

\section{Implications}

This study has implications for both educators of entrepreneurs and future entrepreneurs. Although many attributes associated with being an entrepreneur are innate, some attributes can be developed over time. To be an entrepreneur it is not necessary to possess all the attributes associated with successful entrepreneurs, or to possess all the attributes cited by the participants in this study. It is the responsibility of educators to contribute to the development of these attributes and to inform students accordingly. Future entrepreneurs also need to consider that in addition to several attributes most successful entrepreneurs have learned skills and competencies. More positive than negative associations with entrepreneurship were reported in this study. It is important that educators of entrepreneurship create a realistic image of what it is like to be an entrepreneur, but also that positive associations are highlighted. Although being a risk-taker, and being creative, innovative and original are attributes associated with being a successful entrepreneur, it is the responsibility of educators to inform students that although these attributes are important, they are not vital for entrepreneurial success. Furthermore, students need to understand that these attributes can be nurtured where willingness is present, or partnerships that bring these attributes can be entered into.

\section{Limitations and future research}

Two limitations to this study should be highlighted. Firstly, convenience sampling was used and participants were from NMMU and were students of social sciences only. The findings can thus not be generalised to the entire student population. Secondly, although three researchers guided by the literature analysed and interpreted the words generated by the word association tests, interpretations were subjective and an element of compromise was present when categorising the various words. Several opportunities exist for future research. The students participating in this study were in their first lecture of an entrepreneurship module. It would be interesting to establish whether the results of a word association test done during the last lecture of the module differed significantly from those done during 
the first lecture. In addition, comparisons between words generated by students and entrepreneurs, as well as between participants from different demographic backgrounds, could reveal interesting results.

\section{Acknowledgements \\ Competing interests}

The authors declare that they have no financial or personal relationship(s) that may have inappropriately influenced them in writing this article.

\section{Authors' contributions}

J.E.G. (Nelson Mandela Metropolitan University) was the project leader, and together with S.M.F. (Nelson Mandela Metropolitan University), was responsible for the project design and execution. S.B.S. (Nelson Mandela Metropolitan University) was responsible for the development of the coding framework and provided assistance with data analysis.

\section{References}

Ajzen, I., 1991, 'The theory of planned behaviour', Organisational Behaviour and Human Decision Processes 50(2), 179-211.

Alstete, J.W., 2008, 'Aspects of entrepreneurial success', Journal of Small Business and Enterprise Development 15(3), 584-594. http://dx.doi. org/10.1108/14626000810892364

Baloglu, S. \& McCleary, K.W., 1999, 'A model of destination image formation', Annals of Tourism Research 26(4), 868-897.

Bennett, R., 2006, 'Business lecturers perceptions of the nature of entrepreneurship', International Journal of Entrepreneurial Behaviour Research 12(3), 165-188. http://dx.doi.org/10.1108/13552550610667440

Bergmann, H., 2002, Entrepreneurial attitudes and start-up attempts in ten German regions: An empirical analysis on the basis of the theory of planned behaviour viewed 11 April 2011, from http://www.alexandria.unisg.c/EXPORT/DL/Heiko Bergmann/39675.pdf

Bosch, J., Tait, M. \& Venter, E., 2011, Business Management: An entrepreneurial perspective, Lectern, Port Elizabeth, South Africa.

Brown, U.J., Beale, R.L. \& White-Johnson, S., 2011, 'Perceptions of entrepreneurial intention and risk propensity: Self reliance and self efficacy in college students to encourage knowledge', Review of Business Research 11(5), 169-178.

Cañizares, S.M.S. \& García, F.J.F., 2010, 'Gender differences in entrepreneurial attitudes', Equality Diversity and Inclusion An International Journal 29(8), 766786. http://dx.doi.org/10.1108/02610151011089519

Cooper, D.R. \& Schindler, P.S, 2006, Business Research Methods, 9th edn., McGraw Hill, New York, NY.

Cremer, M., Dingshoff, D., De Beer, M. \& Schoonen, R., 2010, 'Do word associations assess word knowledge? A comparison of $\mathrm{L} 1$ and $\mathrm{L} 2$, child and adult word associations', International Journal of Bilingualism 15(2), 187-204. http://dx.doi. org/10.1177/1367006910381189

Dabic, M., Daim, T., Bayraktoroglu, E., Novak, I. \& Basic, M., 2012, 'Exploring gender differences in attitudes of university students towards entrepreneurship: An international survey', International Journal of Gender and Entrepreneurship 4(3) 316-336. http://dx.doi.org/10.1108/17566261211264172

Davey, T., Plewa, C. \& Struwig, M., 2011, 'Entrepreneurship perceptions and career intentions of international students', Education Training 53(5), 335-352. http:// dx.doi.org/10.1108/00400911111147677

Dawson, C., 2012, 'Push versus pull entrepreneurship: an ambiguous distinction?' International Journal of Entrepreneurial Behaviour and Research 18(6), 697-719. http://dx.doi.org/10.1108/13552551211268139

Donoghue, S., 2000, 'Projective techniques in consumer research', Journal of Family Ecology and Consumer Sciences 28, 47-53.

Drost, E.A., 2010, 'Entrepreneurial intentions of business students in Finland: Implications for education', Advances in Management Journal 3(7), 28-35.

Elmuti, D., Khoury, G. \& Abdul-Rahim, B., 2011, 'Entrepreneur's personality, education and venture effectiveness: Perceptions of palestinian entrepreneurs', Journal of Developmental Entrepreneurship 16(2), 251-268. http://dx.doi.org/10.1142/ S1084946711001823

Friedman, B. \& Aziz, N., 2012, 'Turkey and the United States: Entrepreneurship activity, motives, aspirations, and perceptions', International Journal of Business and Social Science $3(3), 96-108$
Gelderen, M., Brand, M., Van Praag, M., Bodewes, W., Poutsma, E. \& Van Gils, A. 2008, 'Explaining entrepreneurial intentions by means of the theory of planned behaviour', Career Development International 13(6), 538-559. http://dx.doi. behaviour', Career Development
org/10.1108/13620430810901688

Gibson, W.J. \& Brown, A., 2009, Working with qualitative data, Sage, United Kingdom.

Gray, B.A., Farrington, S.M. \& Sharp, G.D., 2010, 'Applying the theory of planned behaviour to entrepreneurial intention', paper presented at the 4th International Business Conference (IBC), Victoria Falls, Zambia, 12-14 October.

Guerrero, L., Claret, A., Verbeke, W., Enderli, G., Zakowska-Biebens, S., Vanhonacker, F. et al., 2010, 'Perception of traditional food products in six European regions using free word association', Food Quality and Preference 21(2), 225-233. http://dx.doi. org/10.1016/j.foodqual.2009.06.003

Hair, J., Babin, B., Money, A. \& Samouel, P., 2003, Essentials of Business Research Methods, Wiley, New York, NY.

Jakubczak, J. \& Rawowska, A., 2013, 'The role of education and culture in the development of youth entrepreneurship in European Union', Management, Knowledge and Learning International Conference, Zadar, Croatia, 19-21 June, pp. 997-1003.

Kakkonen, L.M., 2010, 'International business student's attitude of entrepreneurship', Advances in Business-Related Scientific Research Journal 1(1), 67-77.

Kao, R.W.Y., Kao, K.R. \& Kao, R.R., 2002, Entrepreneurism: A philosophy and a sensible alternative for the market economy, Imperial College, London, UK. http://dx.doi. org/10.1142/p253

Kautonen, T., Van Gelderen, M. \& Tornikoski, E.T., 2013, 'Predicting entrepreneurial behaviour: A test of the theory of planned behaviour', Applied Economics 45(6), 697-707. http://dx.doi.org/10.1080/00036846.2011.610750

Kirkwood, J., 2009, 'Motivational factors in a push-pull theory of entrepreneurship', Gender in Management: An International Journal 24(5), 346-364. http://dx.doi. org/10.1108/17542410910968805

Koll, O., Von Wallpach, S. \& Kreuzer, M., 2010, 'Multi-method research on consumer brand associations: Comparing free associations, storytelling, and collages', Psychology and Marketing 27(6), 584-602. http://dx.doi.org/10.1002/mar.20346

Kolvereid, L. \& Isaksen, E., 2006, 'New business start-up and subsequent entry into self-employment', Journal of Business Venturing 21(6), 566-885. http://dx.doi. self-employment', Journal of Business
org/10.1016/j.jbusvent.2005.06.008

Kolvereid, L., 1996, 'Prediction of employment status choice intentions', Entrepreneurship Theory and Practice 20(3), 47-57.

Kostova, Z. \& Radoynovska, B., 2008, 'Word sssociation test for studying conceptual structures of teachers and students', Bulgarian Journal of Science and Education Policy 2(2), 209-231.

Lüthje, C. \& Franke, N., 2003, 'The making of an entrepreneur: Testing a model of entrepreneurial intent among engineering students at MIT', Resource and Development 33(2), 135-147.

Morris, M.H., Pitt, L.F. \& Berthon, P., 1996, 'Entrepreneurial activity in the Third World informal sector: The view from Khayelitsha', International Journal of Entrepreneurial Behaviour and Research 2(1), 59-76. http://dx.doi. of Entrepreneurial Behaviour

Murphy, P.J., Liao, J. \& Welsch, H.P., 2006, 'A conceptual history of entrepreneurial thought', Journal of Management History 12(1), 12-35. http://dx.doi. org/10.1108/13552520610638256

Nagy, A., Stefan, P., Gyorfy, L. Petru, T.P \& Benyovski, A., 2010, 'Entrepreneuria perceptions and activity - differences and similarities in four eastern european countries', Theoretical and Applied Economics 17(8), 17-28.

Nielsen, M. \& Ingwersen, P., 1999, The word association methodology-a gateway to work-task based retrieval, viewed 03 April 2013, from http://pdf.aminer. org/000/500/632/the_word_as sociation_methodology_a_gateway_to_work task_based.pdf

Orhan, M. \& Scott, D., 2001, 'Why women enter into entrepreneurship: An explanatory model', Women in Management Review 16(5), 232-247. http:// explanatory model', Women in Manage
dx.doi.org/10.1108/09649420110395719

Paço, A.M.F., Ferreira, J.M., Raposa, M., Rodrigues, R.G. \& Dinis, A., 2011, 'Behaviours and entrepreneurial intention: Empirical findings about secondary students', Journal of International Entrepreneurship 9(1), 20-38. http://dx.doi.org/10.1007/ s10843-010-0071-9

Pihie, Z.A.L., 2009, 'Entrepreneurship as a career choice: An analysis of entrepreneurial self-efficacy and intention of university students', European Journal of Socia Sciences 9(2), 338-349.

Prayag, G., 2010, 'Brand image assessment: International visitors perceptions of Cape Town', Marketing Intelligence and Planning 28(4), 462-485. http://dx.doi. org/10.1108/02634501011053577

Pritchard, M.P. \& Funk, D.C., 2010, 'The formation and effect of attitude importance in professional sport', European Journal of Marketing 44(7/8), 1017-1036. http:// in professional sport', European Journal of
dx.doi.org/10.1108/03090561011047508

Roininen, K., Arvola, A. \& Lahteenmaaki, L., 2006, 'Exploring consumers perceptions of local food with two different qualitative techniques: Laddering and word association', Food Quality and Preference17, 20-30. http://dx.doi.org/10.1016/j. foodqual.2005.04.012

Sester, C., Dacremont, C., Deroy, O. \& Valentin, D., 2013, 'Investigating consumers representations of beers through a free association task: A comparison between packaging and blind conditions', Food Quality and Preference 28(2), 475-483. http://dx.doi.org/10.1016/j.foodqual.2012.11.005

Simms, C.D. \& Trott, P., 2006, 'The perceptions of the BMW Mini brand: The importance of historical associations and the development of a model', Journal of Product and Brand Management 15(4), 228-238. http://dx.doi. org/10.1108/10610420610679593 
Simrie, M., Herrington, M., Kew, J. \& Turton, N., 2011, The South African GEM Report, viewed 02 March 2013, from http://www.gem.com

Stephan, U., Lukes, M., Dej, D. \& Richter, P.G., 1987, Attitudes towards and perceptions of entrepreneurs in Central Eastern Europe, viewed 10 May 2013, from https:// lirias.kuleuven.be/bitstream/123456789/266927/2/ute3.pdf

Struwig, F.W. \& Stead, G.B., 2001, Planning, designing and reporting research, Pearson Education, Cape Town, South Africa.

Tausczik, Y.R. \& Pennebaker, J.W., 2009, 'The psychological meaning of words: LIWC and computerized text analysis methods', Journal of Language and Socia Psychology 29(1), 24-54. http://dx.doi.org/10.1177/0261927X09351676
Urban, B., Botha, J.B.H. \& Urban, C.O.B., 2010, The entrepreneurial mindset Heinemann, Kempton Park, South Africa.

Vahie, A. \& Paswan, A., 2006, 'Private label brand image: Its relationship with store image and National brand', International Journal of Retail and Distribution Management 34(1), 67-84. http://dx.doi.org/10.1108/09590550610642828

Xavier, S.R. Kelley, D., Kew, J., Herrington, M. \& Vorderwülbecke, A., 2012, The GEM report, viewed 10 April 2013, from http://www.gem.com

Zaidatol A.L.P., 2009, 'Entrepreneurship as a career choice: An analysis of entrepreneurial self-efficacy and intentions of university students', European Journal of Social Sciences $9(2), 338-349$. 